\title{
FAKTOR RISIKO KEJADIAN KECACATAN TINGKAT 2 PADA PENDERITA KUSTA
}

\author{
Risk Factors Disability Grade 2 on Patients of Leprosy \\ Rismayanti, Jayanti Tandirerung, Indra Dwinata, Jumriani Ansar \\ Bagian Epidemiologi Fakultas Kesehatan Masyarakat Universitas Hasanuddin \\ (antitandirerung@gmail.com)
}

\begin{abstract}
ABSTRAK
Angka penemuan kasus baru kusta di dunia yang terlapor di data World Health Organization (WHO) pada awal tahun 2012 sekitar 219.057 atau sebesar 4,06 (prevalence rate per 10.000 penduduk). Menurut data tahun 2015 di Kabupaten Gowa ditemukan Case Detection Rate (CDR) sebesar 17/100.000 penduduk dengan penderita kusta pada tahun 2014- 2015 sebanyak 224 sedangkan cacat tingkat 2 sebesar 36 kasus. Penelitian ini bertujuan untuk mengetahui faktor risiko kejadian kecacatan tingkat 2 pada penderita kusta di Kabupaten Gowa tahun 20142015. Desain penelitian yang digunakan adalah observational analitik dengan pendekatan studi kasus kontrol. Pengambilan sampel untuk kelompok kasus metode exhaustive sampling dan kelompok kontrol metode simple random sampling. Hasil penelitian menunjukkan variabel yang merupakan faktor risiko kejadian kecacatan tingkat 2 bahwa jenis kelamin $(\mathrm{OR}=1,188 ; 95 \% ; \mathrm{CI}=1,523-2,694)$, pekerjaan $(\mathrm{OR}=2,541 ; 95 \% ; \mathrm{CI}=1,163-5,551)$, Alat Pelindung Diri (APD) $(\mathrm{OR}=5,200 ; 95 \% ; \mathrm{CI}=2,316-11,678)$ dan perawatan diri $(\mathrm{OR}=4,103 ; 95 \% ; \mathrm{CI}=0,181-4,985)$ sedangkan status gizi $(\mathrm{OR}=0,188 ; 95 \% ; \mathrm{CI}=1,523-2,694)$ merupakan faktor protektif kejadian kecacatan tingkat 2 pada penderita kusta. Kesimpulan penelitian ini adalah terdapat hubungan antara jenis kelamin, pekerjaan, alat pelindung diri dan perawatan diri dengan kejadian kecacatan kusta tingkat 2 di Kabupaten Gowa tahun 2014-2015. Kata kunci : Kusta, cacat tingkat 2, kasus kontrol
\end{abstract}

\section{ABSTRACT}

Detection rate of new cases of leprosy in the world reported in data from World Health Organization (WHO) in the early 2012 approximately 219. 057 or 4.06 (prevalence rate per 10,000 population). According to data from 2015 in Gowa found Case Detection Rate (CDR) of 17/100.000 population with leprosy patients in the year 2014 to 2015 is 224 cases while disability grade 2 on leprosy of 36 cases. This study aims to determine the level of disability risk factor grade 2 in patients with leprosy in District Gowa year 2014-2015. The design study is observational analytic with case-control study. Sampling for the case group used exhaustive sampling methods and control groups used simple random sampling. The results showed that the variables are risk factors of disability grade 2 that the sex $(O R=1,188 ; 95 \% C I=1,523$ - 2,694), work $(O R=2,541 ; 95 \% C I=1,163-5,551)$, Personal Protective Equipment (PPE) $(O R=5,200 ; 95 \% C I=2,316$ - 11,678) and self-care $(O R=4,103 ; 95 \% C I=0,181$ 4,985), while the nutritional status $(O R=0,188 ; 95 \% C I=1,523$ - 2,694) were a protective factor to disability level 2 on leprosy. The conclusion of this study is the relationship between sex, work, personal protective equipment and self-care with leprosy disability grade 2 in District Gowa in 2014-2015.

Keywords : Leprosy, disability grade 2, case control 


\section{PENDAHULUAN}

Salah satu penyakit menular yang belum sepenuhnya dapat dikendalikan adalah penyakit kusta. ${ }^{1}$ Penyakit kusta merupakan salah satu jenis penyakit tropis atau tropical disease yang mewabah di Indonesia dan belum dapat ditanggulangi sepenuhnya oleh pemerintah karena masih banyaknya orang yang menderita penyakit tersebut Penyakit kusta terutama menyerang saraf tepi, kulit dan organ tubuh lain kecuali susunan saraf pusat yang apabila tidak didiagnosis dan diobati secara dini dapat menimbulkan kecacatan pada para penderita penyakit kusta. ${ }^{2}$

Angka penemuan kasus baru kusta di dunia yang terlapor di World Health Organization (WHO) pada awal tahun 2012 berjumlah sekitar 219.057 atau sebesar 4,06 (prevalence rateper 10.000 penduduk). ${ }^{3}$ Penemuan kasus baru pada 17 negara, tercatat bahwa ada lebih dari $1000 \mathrm{ka}-$ sus selama tahun 2011 dibandingkan dengan data tahun 2004 sampai dengan tahun 2010, dari data tersebut diperoleh bahwa data kasus total dunia dari tahun 2004 sampai 2011 sebagai berikut 2004 sebesar 407.791 (95\%), 2005 sebanyak 299.036 (96\%), 2006 sebanyak 265.661 (93\%), 2007 sebanyak 258.133 sebanyak (94\%), 2008 sebanyak 249.007 (94\%), 2009 sebanyak 244.796 (93\%), 2010 sebanyak 228.474 (95\%) dan 2011 sebanyak 219.075 (94\%). Delapan belas negara di dunia ini yang mempunyai kontribusi $94 \%$ dari seluruh kasus baru di dunia, karena pada tahun 2012 sudah terbagi 2 yaitu Sudan dan Sudan Selatan. ${ }^{4}$

World Health Organization Weekly Epidemiological Report melaporkan bahwa selama tahun 2012 terdapat 18.994 kasus baru di Indonesia, dengan 15.703 kasus teridentifikasi sebagai kasus kusta tipe Multi Basiller (MB) yang merupakan tipe yang menular. Data kasus kusta baru tahun 2012 tersebut, 6.667 kasus diantaranya oleh diderita oleh kaum perempuan, sedangkan 2.191 kasus diderita oleh anak-anak. Menurut data Profil Kesehatan Indonesia 2013, selama periode 2008-2013, angka penemuan kasus baru kusta pada tahun 2013 merupakan yang terendah yaitu sebesar 6,79 per 100.000 penduduk, sedangkan angka prevalensi kusta berkisar antara 0,79 hingga 0,96 per 10.000 (7,9 hingga 9,6 per 100.000 penduduk) dan telah mencapai target $<1$ per 10.000 penduduk atau $<10$ per 100.000 penduduk, sedangkan pada anak sela- ma periode $2008-2013 .^{5}$

Berdasarkan data dari Dinas Kesehatan Provinsi Sulawesi Selatan tahun 2014, terlihat bahwa dari 24 kabupaten/kota yang ada di Sulawesi Selatan terlihat tren kasus baru dari tahun 2012 - 2014 total kasus baru berturut-turut 2012 sebesar 1.148, 2013 sebesar 1.107 dan 2014 sebesar 1.142 sedangkan tren kasus baru pada tahun 2014 tertinggi ada di kabupaten Bone (199 jiwa), Makassar (157 jiwa) dan Gowa (109 jiwa). Provinsi Sulawesi Selatan jika dilihat dari segi kasus cacat tingkat 2 dari data tahun 2012 - 2014 angka tertinggi ada di kabupaten Gowa sebesar 21 kasus, diikuti oleh Barru sebesar 13 kasus, dan Wajo sebesar 11 kasus, sedangkan pada anak-anak $<15$ tahun berturut-turut dari tahun $2012-2014$ yaitu tertinggi di Makassar (18 jiwa), Gowa (16 jiwa) dan Bone (10 jiwa). ${ }^{6}$

Upaya pengendalian penyakit kusta di dunia menetapkan tahun 2000 sebagai tonggak pencapaian eliminasi. Indonesia berhasil mencapai target ini pada tahun yang sama sebagai upaya global WHO yang didukung The Internastional Federation of Anti-Leprosy Associations (ILEP) mengeluarkan Enchanced Global Strategy for Further Reducing the Disease Burden due to Leprosy (2011-2015). Berpedoman pada panduan WHO ini dan dengan mensinkronkan dengan Rencana Strategi Kementerian Kesehatan untuk tahun 2010-2014, disusun kebijakan nasional pengendalian kusta di Indonesia. ${ }^{1}$ Dari data tersebut menjelaskan bahwa target nasional proporsi kurang dari 1/10.000 tak tercapai. Berdasarkan latar belakang tersebut peneliti tertarik untuk melakukan penelitian di Kabupaten Gowa sebagai kabupaten dengan kasus cacat tingkat 2 tertinggi di Sulawesi Selatan. ${ }^{7}$

\section{BAHAN DAN METODE}

Jenis penelitian yang digunakan adalah penelitian observasional dengan rancangan case control study. Penelitian ini dilakukan pada bulan Februari sampai Maret 2016 di Kabupaten Gowa. Populasi penelitian ini adalah seluruh penderita kusta di Kabupaten Gowa tahun 2014 - 2015 sebanyak 224 orang. Metode yang digunakan dalam pengambilan sampel untuk kelompok kasus adalah exhaustive sampling sedangkan untuk kelompok kontrol adalah simple random sampling. Adapun 
besar sampel yang diperoleh adalah kelompok kasus 34 dan kelompok kontrol 136 sehingga besar keseluruhan sampel adalah 170 orang. Pengumpulan data yang dilakukan dengan wawancara menggunakan kuesioner. Pengolahan data yang dilakukan dengan menggunakan program SPSS. Analisis data yang dilakukan adalah analisis univariat dan bivariat menggunakan uji odss ratio. Analisis univariat yaitu menganalisis distribusi frekuensi dan persentase tunggal terkait dengan variabel yang diteliti sedangkan analisis bivariat dilakukan ter- hadap dua variabel yang diduga berhubungan atau berkorelasi untuk melihat hubungan antara dua variabel dependen dan variabel independen. Data disajikan dengan tabel sederhana/tabel frekuensi (one-way tabulation) untuk analisis univariat dan crosstabulation (two-way tabulation) untuk analisis bivariat yang disertai narasi.

\section{HASIL}

Responden untuk kelompok cacat tingkat 2dan kelompok cacat tingkat 0 dan 1 semua

Tabel 1. Karakteristik Responden

\begin{tabular}{|c|c|c|c|c|c|c|}
\hline \multirow{3}{*}{ Karakteristik } & \multicolumn{4}{|c|}{ Kejadian Kusta } & \multirow{2}{*}{\multicolumn{2}{|c|}{ Jumlah }} \\
\hline & \multicolumn{2}{|c|}{ Cacat Tingkat 2} & \multicolumn{2}{|c|}{ Cacat Tingkat 0 dan 1} & & \\
\hline & $\mathbf{n}$ & $\%$ & $\mathbf{n}$ & $\%$ & $\mathbf{n}$ & $\%$ \\
\hline \multicolumn{7}{|l|}{ Kelompok Umur } \\
\hline$<14$ tahun & 0 & 0,0 & 7 & 5,1 & 7 & 4,1 \\
\hline$\geq 14$ tahun & 34 & 100,0 & 129 & 94,9 & 163 & 95,9 \\
\hline \multicolumn{7}{|l|}{ Jenis Kelamin } \\
\hline Laki-laki & 24 & 70,6 & 91 & 66,9 & 115 & 67,6 \\
\hline Perempuan & 10 & 29,4 & 45 & 33,1 & 55 & 32,4 \\
\hline \multicolumn{7}{|l|}{ Pekerjaan Sebelum Kusta } \\
\hline Tidak Bekerja & 0 & 0,0 & 41 & 30,1 & 41 & 24,1 \\
\hline Petani/Nelayan/Tambak & 14 & 41,2 & 38 & 27,9 & 52 & 30,6 \\
\hline PNS/Polri & 0 & 0,0 & 8 & 5,9 & 8 & 4,7 \\
\hline Karyawan Swasta & 3 & 8,8 & 3 & 2,2 & 6 & 3,5 \\
\hline Buruh/Supir/Tukang & 8 & 23,5 & 19 & 14,0 & 27 & 15,9 \\
\hline Wiraswasta & 9 & 26,5 & 27 & 19,9 & 36 & 21,2 \\
\hline \multicolumn{7}{|l|}{ Pekerjaan Sesudah Kusta } \\
\hline Tidak Bekerja & 2 & 5,9 & 48 & 35,3 & 50 & 29,4 \\
\hline Petani/Nelayan/Tambak & 12 & 35,3 & 36 & 26,5 & 48 & 28,2 \\
\hline PNS/Polri & 0 & 0,0 & 7 & 5,1 & 7 & 4,1 \\
\hline Karyawan Swasta & 3 & 8,8 & 1 & 0,7 & 4 & 2,4 \\
\hline Buruh/Supir/Tukang & 8 & 23,5 & 17 & 12,5 & 25 & 14,7 \\
\hline Wiraswasta & 9 & 26,5 & 27 & 19,9 & 36 & 21,2 \\
\hline \multicolumn{7}{|l|}{ Lama Sakit } \\
\hline$\geq 1$ tahun & 28 & 82,4 & 82 & 60,3 & 110 & 64,7 \\
\hline$<1$ tahun & 6 & 17,6 & 54 & 39,7 & 60 & 35,3 \\
\hline \multicolumn{7}{|c|}{ Menggunakan Alat Pelindung Diri } \\
\hline Ya & 11 & 32,4 & 97 & 71,3 & 108 & 63,5 \\
\hline Tidak & 23 & 67,6 & 39 & 28,7 & 62 & 36,5 \\
\hline \multicolumn{7}{|l|}{ Status Gizi } \\
\hline Kurus (KEK Berat) & 1 & 2,9 & 22 & 16,2 & 23 & 13,5 \\
\hline Kurus (KEK Ringan) & 1 & 2,9 & 12 & 8,8 & 13 & 7,6 \\
\hline Normal & 17 & 50,0 & 72 & 52,9 & 89 & 52,4 \\
\hline Gemuk & 11 & 32,4 & 12 & 8,8 & 23 & 13,5 \\
\hline Obesitas & 4 & 11,8 & 18 & 13,2 & 22 & 12,9 \\
\hline \multicolumn{7}{|l|}{ Perawatan Diri } \\
\hline Ya & 12 & 35,3 & 94 & 69,1 & 106 & 62,4 \\
\hline Tidak & 22 & 64,7 & 42 & 30,9 & 64 & 37,6 \\
\hline
\end{tabular}

Sumber : Data Primer, 2016 
berada pada kelompok umur $\geq 14$ tahun masingmasing sebesar $100 \%$ dan $94,9 \%$ dengan jenis kelamin terbanyak untuk kelompok cacat tingkat 2 dan kelompok cacat tingkat 0 dan 1 , yaitu jenis kelamin laki-laki masing-masing sebesar 70,6\% dan 29,4\% dengan pekerjaan terbanyak sebelum kusta untuk kelompok cacat tingkat 2 sebagai petani/nelayan/tambak sebesar $41,2 \%$ dan kelompok cacat tingkat 0 dan 1 tidak bekerja. Pekerjaan sesudah kusta untuk kelompok cacat tingkat 2 terbanyak bekerja sebagai petani/nelayan/tambak $(35,3 \%)$ dan kelompok cacat tingkat 0 dan 1 tidak bekerja $(35,3 \%)$ dengan lama sakit paling banyak yaitu $\geq 1$ tahun yaitu kelompok cacat tingkat $2(82,4 \%)$ dan kelompok cacat tingkat 0 dan 1 sebesar $(60,3 \%)$. Untuk penggunaan Alat Pelindung Diri (APD) responden kelompok cacat tingkat 2 terbanyak tidak menggunakan APD $(67,6 \%)$ dan kelompok cacat tigkat 0 dan 1 terbanyak menggunakan APD $(71,3 \%)$. Status gizi terbesar untuk kelompok cacat tingkat 2 kelompok cacat tingkat 0 dan 1 yaitu dengan normal masing-masing sebesar $(50 \%)$ dan $(52,9 \%)$ dan kelompok cacat tingkat 2 terbanyak tidak melakukan perawatan diri sebesar $64,7 \%$ dan kelompok cacat tingkat 0 dan 1 terbanyak melakukan perawatan diri sebesar 69,1\% (Tabel 1).

Variabel jenis kelamin menunjukkan pada kelompok cacat tingkat 2 sebagian penderita ber- jenis kelamin laki-laki $(70,6 \%)$ dibandingkan pada kelompok cacat tingkat 0 dan $1(29,4 \%)$. Hasil uji statistik menunjukkan variabel jenis kelamin merupakan faktor risiko kejadian kecacatan kusta tingkat $2(\mathrm{OR}=1,187 ; 95 \% ; \mathrm{CI}=1,523-2,694)$. Variabel pekerjaan menunjukkan pada kelompok cacat tingkat 2 sebagian besar penderita berisiko sebesar $(64,7 \%)$ dibandingkan pada kelompok cacat tingkat 0 dan $1(35,3 \%)$. Hasil uji statistik menunjukkan variabel pekerjaan merupakan faktor risiko kejadian kecacatan kusta tingkat $2(\mathrm{OR}=2,541 ; 95 \%$; $\mathrm{CI}=1,163-5,551)($ Tabel 2).

Variabel alat pelindung diri menunjukkan pada kelompok cacat tingkat 2 sebagian besar berisiko tinggi $(67,6 \%)$ dibandingkan pada kelompok cacat tingkat 0 dan $1(32,4 \%)$. Hasil uji statistik menunjukkan variabel alat pelindung diri merupakan faktor risiko kejadian kecacatan kusta tingkat $2(\mathrm{OR}=5,200 ; 95 \% ; \mathrm{CI}=2,316)$ (Tabel 2). Variabel status gizi menunjukkan pada kelompok cacat tingkat 2 hanya sedikit penderita yang berisiko $(5,9 \%)$ sedangkan kelompok cacat tingkat 0 dan 1 terbanyak berisiko sebesar (94,1\%). Hasil uji statistik menunjukkan variabel status gizi merupakan faktor protektif terhadap kejadian kecacatan kusta tingkat $2(\mathrm{OR}=0,188 ; 95 \% ; \mathrm{CI}=0,181-4,985)$ (Tabel 2). Variabel perawatan diri menunjukkan pada kelompok cacat tingkat 2 sebagian penderita

Tabel 2. Besar Risiko Variabel Independen terhadap Kejadian Kecacatan Tingkat 2 pada Penderita Kusta

\begin{tabular}{|c|c|c|c|c|c|c|c|}
\hline \multirow{3}{*}{ Variabel } & \multicolumn{4}{|c|}{ Kejadian Kusta } & \multirow{2}{*}{\multicolumn{2}{|c|}{ Jumlah }} & \multirow{3}{*}{$\begin{array}{c}\text { OR } \\
95 \% C I \\
(\text { LL-UL) }\end{array}$} \\
\hline & \multicolumn{2}{|c|}{ Cacat Tingkat 2} & \multicolumn{2}{|c|}{ Cacat Tingka 0 dan 1} & & & \\
\hline & $\mathbf{n}$ & $\%$ & $\mathbf{n}$ & $\%$ & $\mathbf{n}$ & $\%$ & \\
\hline \multicolumn{8}{|l|}{ Jenis Kelamin } \\
\hline Risiko tinggi & 24 & 70,6 & 91 & 66,9 & 115 & 66,7 & 1,118 \\
\hline Risiko rendah & 10 & 29,4 & 45 & 33,1 & 55 & 32,4 & $1,523-2,694$ \\
\hline \multicolumn{8}{|l|}{ Pekerjaan } \\
\hline Risiko tinggi & 22 & 64,7 & 57 & 41,9 & 79 & 46,5 & 2,541 \\
\hline Risiko rendah & 12 & 35,3 & 79 & 58,1 & 91 & 53,5 & $1,163-5,551$ \\
\hline \multicolumn{8}{|l|}{ Alat Pelindung Diri } \\
\hline Risiko tinggi & 23 & 67,6 & 39 & 28,7 & 108 & 63,5 & 5,200 \\
\hline Risiko rendah & 11 & 32,4 & 97 & 71,3 & 62 & 36,5 & $2,316-11,678$ \\
\hline \multicolumn{8}{|l|}{ Status Gizi } \\
\hline Risiko tinggi & 2 & 5,9 & 34 & 25,0 & 36 & 21,2 & 0,188 \\
\hline Risiko rendah & 32 & 94,1 & 102 & 75,0 & 134 & 78,8 & $0,181-4,985$ \\
\hline \multicolumn{8}{|l|}{ Perawatan Diri } \\
\hline Risiko tinggi & 22 & 64,7 & 42 & 30,9 & 64 & 37,6 & 4,103 \\
\hline Risiko rendah & 12 & 35,3 & 94 & 69,1 & 106 & 62,4 & $1,859-9,058$ \\
\hline
\end{tabular}

Sumber : Data Primer, 2016 
berisiko tinggi $(64,7 \%)$ dibandingkan kelompok cacat tingkat 0 dan $1(35,3 \%)$. Hasil uji statistik menunjukkan variabel perawatan diri merupakan faktor risiko kejadian kecacatan kusta tingkat 2 $(\mathrm{OR}=4,103 ; 95 \% ; \mathrm{CI}=1,859-9,058)$ (Tabel 2).

\section{PEMBAHASAN}

Umur merupakan faktor yang menentukan bila dihubungkan dengan terjadinya suatu penyakit, karena terdapat banyak penyakit yang hanya terdapat pada golongan umur tertentu. Hal ini merupakan adanya hubungan umur dengan tingkat imunitas atau kekebalan, kemungkinan untuk terpapar terhadap sumber penyakit, aktifitas fisiologi macam-macam jaringan yang mempengaruhi perjalanan penyakit setelah seseorang mengalami infeksi. ${ }^{8}$ Hasil penelitian menunjukkan bahwa kelompok cacat tingkat 2 maupun cacat tingkat 0 dan 1 terbanyak berada pada kelompok umur $\geq 14$ tahun.

Jenis kelamin merupakan pembagian karakteristik orang berdasarkan identifikasi terhadap organ seksual atau pembagian manusia secara biologis berdasarkan penampakan seacara anatomis dan fisiologis. Sifat karakteristik jenis kelamin mempunyai hubungan tersendiri yang cukup erat dengan sifat keterpaparan serta tingkat kerentanan terhadap penyakit tertentu. ${ }^{9}$ Hasil penelitian ini menunjukkan jenis kelamin paling banyak kelompok cacat tingkat 2 dan kelompok cacat tingkat 0 dan 1 adalah jenis kelamin laki-laki.

Hubungan antara pekerjaan dengan penyebaran masalah kesehatan sejak lama diketahui. Menurut Azrul Azwar setiap pekerjaan mempunyai risiko tertentu dan karena itu muncullah masalah penyakit yang dideritanya akan berbeda pula dengan adanya macam pekerjaan yang dimiliki seseorang akan berbeda pula status sosial ekonomi yang dimiliki seseorang yang menyebabkan penyakit yang dideritanya. ${ }^{10}$ Hasil penelitian ini menujukkan pekerjaan yang paling banyak dikerjakan oleh responden kelompok cacat tingkat 2 sebelum maupun sesudah kusta adalah petani/nelayan/tambakdan kelompok cacat tingkat 0 dan 1 untuk pekerjaan sebelum dan sesudah kusta tidak bekerja.

Pada penelitian ini ditemukan bahwa secara umum lama sakit penderita kusta paling banyak $\geq 1$ tahun pada kelompok cacat tingkat 2 dan kelompok cacat tingkat 0 dan 1 . Alat pelindung diri kelompok cacat tingkat 2 terbanyak tidak menggunakan alat pelindung diri, sedangkan kelompok kontrol terbanyak menggunakan alat pelindung diri.

Penggunaan alat pelindung diri dalam melakukan setiap kegiatan berupa pekerjaan sangat penting untuk menjaga diri dari berbagai hal buruk yang dapat menimbulkan gangguan kesehatan berupa kecacatan dan lain sebagainya. Alat pelindung diri merupakan salah satu alternatif yang digunakan untuk mencegah bahaya dilingkungan kerja, baik secara fisik maupun kimiawi. ${ }^{11}$ Adapun alat pelindung diri untuk penyakit kusta umumnya memiliki standarisasi khusus. Hal inilah yang menyebabkan kurangnya perhatian penderita terhadap penggunaan alat pelindung diri dalam kehidupan sehari-hari. Apalagi alat pelindung diri ini harus disediakan sendiri oleh penderita dan dapat menganggu dalam kenyamanannya beraktivitas. Namun, alat pelindung diri kusta yang baik seharusnya dapat melindungi penderita dari risiko kecacatan.

Alat pelindung diri yang disediakan fasilitas kesehatan seperti rumah sakit hanya terbatas pada sepatu khusus kusta. Namun, mengingat bentuknya yang sedikit agak berbeda dari sepatu yang digunakan oleh kebanyakan orang pada umumnya, penderita cenderung merasa minder untuk menggunakannya, apalagi didukung oleh stigma yang masih cukup besar dikalangan masyarakat mengenai kusta. Penggunaan APD pada mata secara umum bahwa hanya $21,2 \%$ penderita yang menggunakan, pada tangan tangan hanya digunakan sebesar $8,8 \%$ penderita saja, sedangkan pada kaki hanya sebesar $15,3 \%$ penderita saja yang menggunakan. Secara umum, hasil penelitian di Gowa memperlihatkan bahwa hanya $29,4 \%$ yang menggunakan alat pelindung diri sedangkan $70,6 \%$ tidak menggunakan alat pelindung diri.

Salah satu faktor yang mempengaruhi status gizi adalah asupan makanan, pada orang yang terinfeksi tubuhnya akan mengalami defisiensi gizi hal ini diakibatkan oleh asupan gizi yang tidak mencukupi sehingga tubuh akan melakukan katabolisme besar-besaran sehingga memperburuk kerja dari tubuh untuk mengatasi infeksi. ${ }^{12}$ Penelitian di Gowa ini juga tidak memperlihatkan adanya hubungan yang berarti antara status gizi dengan kejadian kecacatan tingkat 2 pada penderita kusta. 
Berdasarkan pengamatan hal ini terjadi karena status gizi penderita hanya diukur berdasarkan kartu penderita yang dilihat dan kartu penderita itu ada saat penderita sudah dinyatakan menderita kusta. Kita tidak mengukur status gizi penderita sebelum terjadi reaksi kusta dan sebelum terinfeksi penyakit kusta. Penelitian ini sejalan dengan penelitian yang dilakukan oleh Safriani Djufri di RS Thajuddin Thalid Makassar bahwa dari hasil uji statistik odds ratio diperoleh status gizi merupakan faktor protektif terhadap terjadinya kecacatan tingkat 2 dan tidak ada hubungan yang bermakna pada kecacatan tingkat $2 .{ }^{13}$ Adapun penelitian tidak sejalan dengan penelitian Murniati di RS Kusta Makassar dimana ada hubungan antara status gizi $(p=0,03)$ dengan kejadian kusta. ${ }^{14}$

Perawatan diri juga sangat penting dilakukan penderita untuk menghindari terjadinya cacat baru pada penderita kusta. Penderita membiasakan merawat diri dengan teratur dengan membiasakan menghindari luka sepanjang hari, memeriksakan dan merawat kulit secara rutin serta membiasakan merawat luka sendiri mungkin dengan baik dan benar. ${ }^{15}$ Perawatan diri kelompok cacat tingkat 2 terbanyak tidak melakukan perawatan diri sedangkan kelompok cacat tingkat 0 dan 1 terbanyak melakukan perawatan diri. Hasil penelitian menunjukkan bahwa penderita yang tidak melakukan perawatan diri berisiko sebesar 4,103 kali dibandingkan penderita yang melakukan perawatan diri. Hasil penelitian di Kabupaten Gowa mengenai perawatan diri bahwa untuk penderita dengan cacat tingkat 2 hanya sebesar $12(35 \%)$ yang melakukan perawatan diri dan sebanyak $22(64,7 \%)$ tidak melakukan perawatan diri. Jenis perawatan yang paling banyak dilakukan adalah latihan menutup mata, membersihkan mata dengan kain basah serta memberi obat tetes mata sebesar $35,3 \%$, tangan paling banyak dilakukan merendam, menggosok dan mengoleskan minyak 35,3\%, kaki dengan luka dibersihkan, jaringan yang mati dikikis, dan perban diganti secara teratur masing-masing sebesar $35,3 \%$ pada penderita cacat tingkat 2 . Penelitian Nugroho Susanto di Kabupaten Sukoharjo bahwa ada hubungan antara perawatan diri dengan tingkat kecacatan didapatkan hasil analisis $T^{=}=0,770 ; p=0,000$. Hal ini menunjukkan bahwa terdapat hubungan yang signifikan antara variabel perawatan diri dengan tingkat kecacatan pada $\alpha=$
$0,05 \cdot{ }^{16}$

\section{KESIMPULAN DAN SARAN}

Penelitian ini menunjukkan bahwa jenis kelamin $(\mathrm{OR}=0,118 ; 95 \%$; $\mathrm{CI}=1,523-2,694)$, pekerjaan $(\mathrm{OR}=2,541 ; 95 \% ; \mathrm{CI}=1,163-5,551)$, alat pelindung diri $(\mathrm{OR}=5,200 ; 95 \% ; \mathrm{CI}=2,316-11,678)$ dan perawatan diri $(\mathrm{OR}=4,103 ; 95 \%$; $\mathrm{CI}=1,859$ $9,058)$ merupakan faktor risiko kejadian kecacatan tingkat 2 pada penderita kusta di Kabupaten Gowa tahun 2014-2015 sedangkan status gizi $(\mathrm{OR}=0,188 ; 95 \% ; \mathrm{CI}=0,181-4,985)$ hanyalah sebagai faktor protektif terhadap kejadian kecacatan kusta tingkat 2.

Penderita kusta yang bekerja sebagai petani, nelayan, dan buruh/tukang hendaknya meningkatkan kewaspadaan terhadap terjadinya luka di tempat kerja sehingga perlunya menggunakan APD saat bekerja dan merawat/membersihkan APD sehabis digunakan.Penderita hendaknya selalu memperhatikan kondisinya dengan senantiasa melakukan perawatan mandiri untuk mencegah terjadinya luka sehingga kecacatan yang diakibatkan dapat dihindari dan untuk mencegah infeksi.

\section{DAFTAR PUSTAKA}

1. Depkes, RI. Buku Pedoman Nasional Pengendalian Penyakit Kusta Direktorat Jenderal Pengendalian Penyakit dan Penyehatan Lingkungan. Jakarta : Cipta Press; 2012.

2. Frambusia, SKd. Modul Pelatihan Program P2 Kusta bagi UPK. Jakarta: Kementrian Kesehatan Republik Indonesia; 2007.

3. WHO. Global Burden Of Leprosy at the end of 2010 Weekly Epidemiolog. 2 ed. Geneva: World Health Organization; 2011.

4. WHO. Global Burden Of Leprosy at the end of 2010 Weekly Epidemiolog. 3 ed. Geneva: World Health Organization; 2012.

5. Profil Kesehatan Indonesia. Profil Data Kesehatan Indonesia Tahun 2013. Jakarta: Departemen Kesehatan Indonesia; 2013.

6. Dinkes Sul-Sel. Profil Kesehatan Provinsi Sulawesi Selatan Tahun 2014. Makassar: Dinas Kesehatan Sulawesi Selatan; 2014.

7. Profil Kesehatan Kabupaten Gowa Tahun 2014. Gowa: Dinas Kesehatan Kabupaten Gowa; 2014.

8. Sutrina, B. Pengantar Epidemiologi. Jakarta: 
Binarupa Aksara. 2009.

9. Muhammad, D. Analisis Faktor Risiko Kecacatan pada Penderita Kusta di Kabupaten Wajo Tahun 2007-2012 [Tesis]. Makassar: Universitas Hasanuddin; 2013.

10. A, Azwar. Faktor Risiko Penyakit Akibat Kerja. Jakarta: Balai Penerbit FK UI; 1998.

11. Harrington. Alat Pelindung Diri pada Pekerja. London: University College Medical School of London; 2003.

12. Huzzein. Journal The Correlation of Application Universal Precausationor Prevent Degree of Disability Clients Leprosy in the Workplace of Jenggawah Health Centers and Tempurejo Health Centers at Jember 2014. E-Journal Pustaka Kesehatan. 2015;3(1):11-23.

13. Djufri, S. Faktor Risiko Kejadian Kecacatan Tingkat 2 pada Penderita Kusta di RS Tha- juddin Thalid Makassar Tahun 2009 [Skripsi]. Makassar : Universitas Hasanuddin; 2012.

14. Murniati. Analisis Faktor Risiko dalam Individu dan Luar Individu yang Berhubungan dengan Kejadian Kusta di RS Kusta Makassar, Sulawesi Selatan [Tesis]. Jogjakarta : Universitas Gajah Mada; 2009.

15. Muhammad, A. Hubungan Jenis Kelamin dengan Kejadian Cacat Tingkat 2 pada Penderita Kusta di Kabupaten Lamongan Tahun 20112012 [Tesis]. Jakarta: Universitas Indonesia; 2012.

16. Nugroho, S. Faktor-Faktor yang Berhubungan dengan Tingkat Kecacatan Penderita Kusta Kajian di Kabupaten Sukoharjo, Universitas Gajah Mada. Jurnal Kesehatan Masyarakat Indonesia. 2006;3(16):1-92. 